\title{
announcements
}

\section{On the Move}

Dr E. B. Carstens, Department of Microbiology, Centre Hospitalier Universitaire, Sherbrooke, Canada, to Institute of Genetics, University of Cologne, Germany.

Details of changes of department, sabbaticals, where leave will be taken and so on should be sent to On the Move; there is no charge for this service.

\section{Appointments}

Dr E. H. Francis, to the Chair of Earth Sciences, University of Leeds, from 1 October 1977.

Professor H. Charnock, Director of the Institute of Oceanographic Sciences, to the Chair of Physical Oceanography, University of Southampton, from 1 February 1978.

Dr P. Crutzen, to Director of the Atmospheric Quality Division of the National Center for Atmospheric Research (NCAR).

Professor R. N. Pryor, to PresidentElect of the Institution of Mining and Metallurgy from 20 June 1978.

\section{Awards}

Dr G. N. Hounsfield has been awarded the Royal Society Mullard Award for $1977(£ 1,000)$ in recognition of his conception and development of the EMIScanner, a computerised threedimensional X-ray system.

Two Technology Writers' Awards, sponsored by ITT Business Systems under the auspices of British science writers, will be awarded for work published between 1 January and 31 December 1977. One will be for work published in professional periodicals, trade and technical magazines, or national and regional newspapers, the other for material broadcast on radio or television. Both prizes will be $£ 1,000$ cash and $£ 500$ for travel or equipment. All entries are by submission (to $J$. Anstiss, MPR Ltd, 293 Gray's Inn Road, London WC1, UK), and it is hoped to announce the winners in February 1978.

\section{Marconi International Fellowship}

Nominations, to be received by 15 October 1977, are invited for the 1978 Fellowship $(\$ 25,000)$, established in 1974 to commemmorate Guglielmo Marconi's contributions to scientific discovery, engineering and technology. The recipient, in recognition of out- standing contribution in these fields, is invited to give a public lecture based on the work during the 12 months following presentation. Address all enquiries to The Marconi International Fellowship Council, Aspen Institute for Humanistic Studies, 1919 Fourteenth Street, No. 811, Boulder, Colorado 80302, USA.

\section{National Academy of Sciences Committee on Aerobiology}

A new programme has been outlined by a NAS committee to encourage the advancement of Aerobiology as a discrete science. The NAS wish to compile a register of aerobiologists, giving details of research interests. Please send relevant information to National Research Council, Assembly of Life Sciences, 2101 Constitution Avenue, Washington, DC 20418.

\section{Meetings}

30 September, Fine Structure and Chemical Shifts in Electron Spectroscopy, London, UK (The Institute of Physics, 47 Belgrave Square, London SW1, UK).

30 September-1 October, Measurement in Biological Electron Microscopy, Bristol, (Physiology Departmental Office, The Medical School, University of Bristol, Bristol, UK).

2-8 October, 2nd International Colloquium on Physical and Chemical Information Transfer in Regulation of Reproduction and Ageing, Varna, Bulgaria (Secretariat, Colloquium '77, Central Laboratory of Biophysics, Acad. G. Bonchev Str. B1. 6, 1113 Sofia, Bulgaria).

3-5 October, 5th Biennial Symposium on Turbulence, Rolla (Turbulence Symposium, Extension Division, University of Missouri-Rolla, Rolla, Missouri 65401).

3-7 October, Thermodynamics of Magnetic Fluids, Udine, Italy (B. Berkovsky, Science Sector, UNESCO, 7 place de Fontenoy, 75700 Paris, France).

5 October, Technology Transfer from the Nuclear Industry, Harewell (The Meetings Secretary, The Institution of Metallurgists, Northway House, Whetstone, London, UK).

7-11 October, VII International Congress of Essential Oils, Kyoto (Y. Kato, Secretary General, VII International Congress of Essential Oils, c/o Kyoto International Conference Hall, Takaraike, Sakyo-ku Kyoto, 606 Japan).

10-13 October, XXV International Meeting on Transportation and Com- munications, Genoa (International Institute of Communication, Villa Piagio, Via Pertinance, 16125 Genova, Italy).

11-13 October, 4th Annual UMR-DNR Conference on Energy, Rolla (N. Fleming, Conference Coordinator, Extension Division, University of Missouri-Rolla, Rolla, Missouri 65401).

11-13 October, AGU Conference on Oceanic Fronts, New Orleans (American Geophysical Union, 1909 K St, NW, Washington, DC 20006).

17-18 October, Conference on Genetic Epidemiology, Hawaii (N. E. Morton, School of Public Health, University of Hawaii, Honolulu 96822).

17-21 October, 1st International Congress on Phosphorus Compounds and their Non-fertiliser Uses, Rabat, Morocco (IMPHOS (World Phosphate Rock Institute), 8 rue de Penthièvre, 75008 Paris, France).

19-21 October, Symposium on Current Topics in Drug Research, Uppsala ( $R$. Dahlbom, Biomedical Center, University of Uppsala, Box 574, S-751 23 Uppsala, Sweden).

24-26 October, ASTM Symposium on Erosion: Prevention and Useful Applications, Vail, Colo (Miss J. B. Wheeler, ASTM, 1916 Race Street, Philadelphia, Pa. 19103).

24-28 October, International Conference on Water Chemistry of Nuclear Reactor Systems, Bournemouth (The Conference Office, Institution of Civil Engineers, 1-7 Great George Street, London SW1, UK).

25-28 October, International Conference-Radar 77, London, UK (The Institution of Electrical Engineers, Savoy Place, London WC2, UK).

31 October-3 November, Advancing Energy Technology, Eastbourne (The Institute of Fuel, 18 Devonshire Street, Portland Place, London W1, UK).

31 October-4 November, Symposium on Radioimmunoassay, and Related Procedures in Medicine, Berlin (International Atomic Energy Agency, PO Box 590, A-1011 Vienna, Austria).

31 October-4 November, Conference on Water Chlorination : Envirommental Impact and Health Effects, Gatlinburg (R. L. Jolley, Chemical Technology Division, Oak Ridge National Laboratory, PO Box X, Oak Ridge, Tennessee 37830).

2-3 November, International Symposium on Polarography in Action, London, UK (The Secretary, Scientific Symposia Ltd, 42-43 Gerrard Street, London W1, UK). 